\title{
A Preliminary Investigation for Standardization of Hydroalcoholic Extract of Mucuna pruriens (Kapikaccu): An Important Drug Used to Treat Parkinson's Disease in Ayurveda
}

\author{
Gangadhara Swamy ${ }^{1}$ Rajendra Holla ${ }^{2}$ Suresh R. Rao ${ }^{1}$ \\ ${ }^{1}$ Department of Anatomy, Subbaiah Institute of Medical Sciences \\ and Research Centre, Shivamogga, Karnataka, India \\ 2Department of Pharmacology, K. S. Hegde Medical Academy, \\ Mangalore, Karnataka, India \\ J Health Allied Sci NU 2019;9:85-90
}

\begin{abstract}
Address for correspondence Suresh R. Rao, PhD, Department of Anatomy, Subbaiah Institute of Medical Sciences and Research Centre, Shivamogga, Karnataka 577222, India (e-mail: s4chavan@yahoo.co.in).
\end{abstract}

Abstract

Keywords
- hydroalcoholic extract
of Mucuna pruriens
- phytochemical
analysis
- HPTLC

Establishment of standardization for the Ayurvedic formulations is most important for its chemical compounds, biological action, and its quality reassurance in production and manufacturing of traditional herbal medicines. As most of the drugs are standardized, drug companies are using substitute drugs instead of true drugs. So, to make finest superiority drugs it is necessary to validate raw drugs. Observing the existing trend in mind, hydroalcoholic extract of Mucuna pruriens seeds (HAMP) was subjected to standardize the procedures for phytochemical tests. The separation of bioactive substances from HAMP was performed using both manual methods and high-profile thin layer chromatography. From the current study, it is revealed that the seed contains alkaloids, steroids, carbohydrates, tannins, flavonoids, and coumarins, which gave the medicine numerous therapeutic properties.

\section{Introduction}

As per the World Health Organization (WHO), approximately 80 to $85 \%$ of the world's population use herbal medicines for their health care. ${ }^{1,2}$ As the usage of herbal medicines has increased, issues regarding their quality, safety, and efficacy have risen up. ${ }^{3}$ WHO has even evolved guidelines for the validation of plant-based drugs. ${ }^{4}$ As standardization is a burning topic in Ayurvedic drug formulations, it is most important for the establishment of its biological activity, chemical profile, and quality assurance in production and manufacturing of herbal drugs. As Ayurvedic medicines are supervised by the Drugs and Cosmetics Act, there is increased awareness for quality assurance to the public and the necessity for developing the standards for the purpose of quality control by the manufacturers as well as by the drug control authorities. ${ }^{5}$

Mucuna pruriens (MP) commonly called velvet bean is a tropical legume indigenous tree in Africa and tropical Asia.
As it is one of the best sources of protein content in many African countries, it is used as food for humans and also as animal feed. ${ }^{6}$ It is used as a forage, fallow, green manure crop enriched with proteins, amino acids, glutathione, lecithin, gallic acid, $\beta$-sitosterol, and L-3,4-dihydroxyphenylalanine (L-DOPA), vitamins such as niacin, ascorbic acid, synthesizing dopamine linked with mood and sex. ${ }^{7}$ The fatty acids present are palmitic, oleic, stearic, behenic, linoleic, and linolenic acid. It possesses antioxidant, hypoglycemic, lipid-lowering, and neuroprotective activities. ${ }^{8}$ MP seedpods are covered with hair which are rich in 5-hydroxytryptamine and if they come in touch with the skin it causes severe itching. ${ }^{9,10}$ In Ayurveda, to treat Parkinson's disease (PD) (also called Kampavata), MP has been used for a long time. Many kinds of research have found the presence of L-DOPA in the seeds of MP. Various clinical trials have been performed on PD patients for its safety, bioavailability, and action. ${ }^{11,12}$ It is reported that MP has antiurolithiatic, ${ }^{13}$ antidiabetic, ${ }^{14-16}$ anticancer, and antioxidant properties. ${ }^{17}$ As the plant has
DOI https://doi.org/

10.1055/s-0039-3400169

ISSN 2582-4287.
Copyright @2019 Nitte University

(Deemed to be University)
License terms

(요 (1) $\Theta \circledast$ 
numerous therapeutic properties and uses in the field of medicine, one should be aware of its photochemistry.

So to prepare the best quality MP drug, it is necessary to authenticate raw drugs. Keeping the current trend in mind, it was subjected to standardize the procedures. For the current study, genuinity indicating parameters for MP were derived.

\section{Materials and Methods}

\section{Plant Material}

The seeds of MP were collected from the Sri Dharmastala Ayurveda Medical College and Research Center, Udupi, Karnataka, India. The plant material was stored in ambient conditions for further study.

\section{Preparation of Extracts}

The MP seeds were dried in the shade and powdered in our research laboratory with the help of pulverizer. The hydroalcoholic extract of Mucuna pruriens (HAMP) was prepared by soaking $500 \mathrm{~g}$ of powdered seeds of the MP in $2 \mathrm{~L}$ of $50 \%$ ethanol and 50\% cold distilled water for 24 hours, filtered, and concentrated by evaporating on water bath till free from water. The extract is stored in an airtight container under normal temperature. ${ }^{18}$

Phytochemical tests, such as tests for alkaloids, steroids, saponins, tannins, flavonoids, phenol, coumarins, triterpenoids, carboxylic acid, resin, quinine, and high-profile thin layer chromatography (HPTLC), were performed as per the WHO guidelines, ${ }^{19}$ Ayurvedic Pharmacopoeia, ${ }^{20}$ and Indian Pharmacopoeia. ${ }^{21}$

\section{Preliminary Phytochemical Tests Tests for Alkaloids}

a. Dragendroff's test: A few milligrams of HAMP extract were dissolved in alcohol and few drops of acetic acid and Dragendroff's reagent were added, and then shaken well. An orange-red precipitate formed indicates the presence of alkaloids. ${ }^{22}$

b. Wagners's test: A few milligrams of extract were dissolved in acetic acid and a few drops of Wagner's reagent were added. A reddish-brown precipitate formed indicates the presence of alkaloids. ${ }^{23}$

c. Mayer's test: A few milligrams of HAMP extract were dissolved in acetic acid and few drops of Mayer's reagent were added. A dull white precipitate will be formed if the alkaloids are present. ${ }^{24}$

d. Hager's test: A few milligrams of extract were dissolved in acetic acid and $3 \mathrm{~mL}$ of Hager's reagent was added. Formation of a yellow precipitate indicates the presence of alkaloids. ${ }^{25}$

\section{Tests for Carbohydrates}

a. Molisch test: To the HAMP, along the sides of the test tube, $1 \mathrm{~mL}$ of $\alpha$-naphthol solution and concentrated sulfuric acids were added. If carbohydrates are present then a violet color will be formed at the junction of the two liquids. ${ }^{26}$ b. Fehling's test: Few milligrams of HAMP were mixed with equal quantities of Fehling's solution A and B. The mixture was warmed in a water bath. If carbohydrates are present then the formation of a brick-red precipitate is seen. ${ }^{27}$

c. Benedict's test: To $5 \mathrm{~mL}$ of Benedict's reagent, a few milligrams of the extract were added, and boiled for 2 minutes and cooled. Formation of a red precipitate indicates the presence of carbohydrates. $^{28}$

\section{Test for Steroids}

a. Libermann-Burchard test: To the extract dissolved in chloroform, $1 \mathrm{~mL}$ of acetic acid and $1 \mathrm{~mL}$ of acetic anhydride were added, then heated on a water bath and cooled. Few drops of concentrated sulfuric acid were added along the sides of the test tube. The appearance of a bluish green color indicates the presence of steroids. ${ }^{29}$

b. Salkowski test: The HAMP was dissolved in chloroform and equal volume of concentrated sulfuric acid was added. Formation of bluish red to a cherry red color in chloroform layer and green fluorescence in the acid layer indicates the presence of steroids. ${ }^{30}$

\section{Test for Saponins}

To a few milligrams of HAMP, sodium bicarbonate $\left(\mathrm{NaHCO}_{3}\right)$ was added and shaken. Stable froth formation indicates the presence of saponin. ${ }^{31}$

\section{Test for Tannins}

To the HAMP, a few drops of dilute solution of ferric chloride $\left(\mathrm{FeCl}_{3}\right)$ were added. Formation of dark blue color shows the presence of tannins. ${ }^{32}$

\section{Test for Flavonoids}

Shinoda's test: To HAMP in alcohol, a few magnesium turnings and few drops of concentrated hydrochloric acid were added and heated on a water bath. Formation of red to pink color indicates the presence of flavonoids. ${ }^{33}$

\section{Test for Phenol}

To HAMP in alcohol, add two drops of alcoholic ferric chloride. Formation of blue to blue-black indicates the presence of phenol. ${ }^{34}$

\section{Test for Coumarins}

To the HAMP in alcohol, a few drops of $2 \mathrm{~N}$ sodium hydroxide $(\mathrm{NaOH})$ solutions were added. Dark yellow color formation indicates the presence of coumarins. ${ }^{32}$

\section{Test for Triterpenoids}

The HAMP was warmed with tiny bits and a few drops of vinyl chloride. Formation of pink color indicates the presence of triterpenoids. ${ }^{35}$

\section{Test for Carboxylic Acid}

HAMP dissolved in water is treated with sodium bicarbonate. Brisk effervescence indicates the presence of carboxylic acid. ${ }^{36}$ 


\section{Test for Resin}

Few milligrams of the sample were mixed with water and acetone. Turbidity indicates the presence of resin. ${ }^{37}$

\section{Test for Quinine}

Few milligrams of HAMP were treated with $0.5 \%$ of $\mathrm{NaOH}$. If quinine is present it gives deep coloration like pink, purple, or red. ${ }^{35}$

\section{High-Profile Thin Layer Chromatography}

One gram of powdered sample was dissolved in $10 \mathrm{~mL}$ ethanol and kept for cold percolation for 24 hours and filtered. 4,8 , and $12 \mu \mathrm{L}$ of the above sample were applied to a precoated silica gel F254 on aluminum plates to a bandwidth of $7 \mathrm{~mm}$ using Linomat 5 TLC applicator. The plate was developed in n-butanol:acetic acid:water (4:1:1). The developed plates were visualized in short ultraviolet (UV) and long UV, and then derivatized with vanillin sulfuric acid reagent and scanned under 254 and $366 \mathrm{~nm}$ and white light at $620 \mathrm{~nm}$. Retention factor $\left(R_{f}\right)$, the color of the spots, and densitometric scan were recorded. ${ }^{38}$

\section{Results and Discussion}

Qualitative and quantitative analysis of phytochemical compounds present in HAMP by colorimetry (-Tables 1 and 2), photo documentation ( - Fig. 1), the unique $R_{f}$ values (-Table 3), densitometric scan, and densitogram (-Figs. 2-4) were obtained at different wavelengths from HPTLC.

Concentration of different phytochemicals of HAMP detected by HPTLC at wavelength $366 \mathrm{~nm}$ are alkaloids (17.13\%), carbohydrates (17.19\%), steroids (19.59\%), tannins (25.86\%), flavonoids (10.81\%), and Coumarins (9.42\%).

The phytochemical tests were performed to serve as a preliminary test for the standardization of the HAMP formulation. Tests for alkaloids, carbohydrates, steroids, tannins, flavonoids, and coumarins are positive for HAMP. Photo

Table 1 Results of preliminary phytochemical tests

\begin{tabular}{|l|l|}
\hline Test & HAMP \\
\hline Alkaloid & + \\
\hline Steroid & + \\
\hline Carbohydrate & + \\
\hline Tannin & + \\
\hline Flavonoids & + \\
\hline Saponins & - \\
\hline Terpenoid & - \\
\hline Coumarins & + \\
\hline Phenol & - \\
\hline Carboxylic acid & - \\
\hline Resins & - \\
\hline Quinine & - \\
\hline Amino acids & - \\
\hline
\end{tabular}

Abbreviation: HAMP, hydroalcoholic extract of Mucuna pruriens seeds.
Table 2 Results of preliminary phytochemical tests

\begin{tabular}{|c|c|c|c|}
\hline S. no. & Tests & $\begin{array}{l}\text { Color if } \\
\text { positive }\end{array}$ & HAMP \\
\hline \multirow[t]{5}{*}{1} & \multicolumn{3}{|l|}{ Alkaloids } \\
\hline & $\begin{array}{l}\text { Dragendroff's } \\
\text { test }\end{array}$ & $\begin{array}{l}\text { Orange precip- } \\
\text { itate }\end{array}$ & Red solution \\
\hline & Wagner's test & Red precipitate & Red solution \\
\hline & Mayer's test & $\begin{array}{l}\text { Dull white } \\
\text { precipitate }\end{array}$ & $\begin{array}{l}\text { Dull white precip- } \\
\text { itate }\end{array}$ \\
\hline & Hager's test & $\begin{array}{l}\text { Yellow precip- } \\
\text { itate }\end{array}$ & \\
\hline \multirow[t]{3}{*}{2} & \multicolumn{3}{|l|}{ Steroids } \\
\hline & $\begin{array}{l}\text { Liebermann- } \\
\text { Burchard test }\end{array}$ & Bluish green & $\begin{array}{l}\text { Green color is } \\
\text { appeared in the } \\
\text { chloroform and } \\
\text { colorless in the } \\
\text { acid layer }\end{array}$ \\
\hline & Salkowski test & $\begin{array}{l}\text { Bluish red to } \\
\text { cherry red }\end{array}$ & $\begin{array}{l}\text { Red solution at } \\
\text { the upper layer } \\
\text { and clear at the } \\
\text { base layer }\end{array}$ \\
\hline \multirow[t]{4}{*}{3} & \multicolumn{3}{|l|}{ Carbohydrate } \\
\hline & Molisch test & Violet ring & Violet ring \\
\hline & Fehlings test & $\begin{array}{l}\text { Brick red pre- } \\
\text { cipitate }\end{array}$ & Ink blue solution \\
\hline & Benedicts test & Red precipitate & $\begin{array}{l}\text { Bluish green } \\
\text { solution }\end{array}$ \\
\hline \multirow[t]{2}{*}{4} & \multicolumn{3}{|l|}{ Tannin } \\
\hline & With $\mathrm{FeCl}_{3}$ & $\begin{array}{l}\text { Dark blue } \\
\text { or green or } \\
\text { brown }\end{array}$ & Dark brown \\
\hline \multirow[t]{2}{*}{5} & \multicolumn{3}{|l|}{ Flavonoids } \\
\hline & Shinoda's test & Red to pink & Light pink \\
\hline \multirow[t]{2}{*}{6} & \multicolumn{3}{|l|}{ Saponins } \\
\hline & With $\mathrm{NaHCO}_{3}$ & Stable froth & No froth \\
\hline \multirow[t]{2}{*}{7} & \multicolumn{3}{|l|}{ Triterpenoids } \\
\hline & $\begin{array}{l}\text { Tin and thionyl } \\
\text { chloride test }\end{array}$ & Red & Gray color \\
\hline \multirow[t]{2}{*}{8} & \multicolumn{3}{|l|}{ Coumarins } \\
\hline & With $2 \mathrm{~N} \mathrm{NaOH}$ & Yellow & Yellow color \\
\hline \multirow[t]{2}{*}{9} & \multicolumn{3}{|l|}{ Phenols } \\
\hline & $\begin{array}{l}\text { With alcoholic } \\
\text { ferric chloride }\end{array}$ & $\begin{array}{l}\text { Blue to blue } \\
\text { black, brown }\end{array}$ & Dark brown \\
\hline \multirow[t]{2}{*}{10} & \multicolumn{3}{|l|}{ Carboxylic acid } \\
\hline & $\begin{array}{l}\text { With water and } \\
\mathrm{NaHCO}_{3}\end{array}$ & $\begin{array}{l}\text { Brisk efferves- } \\
\text { cence }\end{array}$ & No effervescence \\
\hline \multirow[t]{2}{*}{11} & \multicolumn{3}{|l|}{ Resin } \\
\hline & $\begin{array}{l}\text { With aqueous } \\
\text { acetone }\end{array}$ & Turbidity & No turbidity \\
\hline \multirow[t]{2}{*}{12} & \multicolumn{3}{|l|}{ Quinine } \\
\hline & $5 \% \mathrm{NaOH}$ & $\begin{array}{l}\text { Pink/purple/ } \\
\text { red }\end{array}$ & $\begin{array}{l}\text { Green colored } \\
\text { solution }\end{array}$ \\
\hline \multirow[t]{2}{*}{13} & Amino acids & & \\
\hline & $\begin{array}{l}\text { Ninhydrine } \\
\text { reagent }\end{array}$ & Purple color & Green solution \\
\hline
\end{tabular}

Abbreviation: HAMP, hydroalcoholic extract of Mucuna pruriens seeds. 


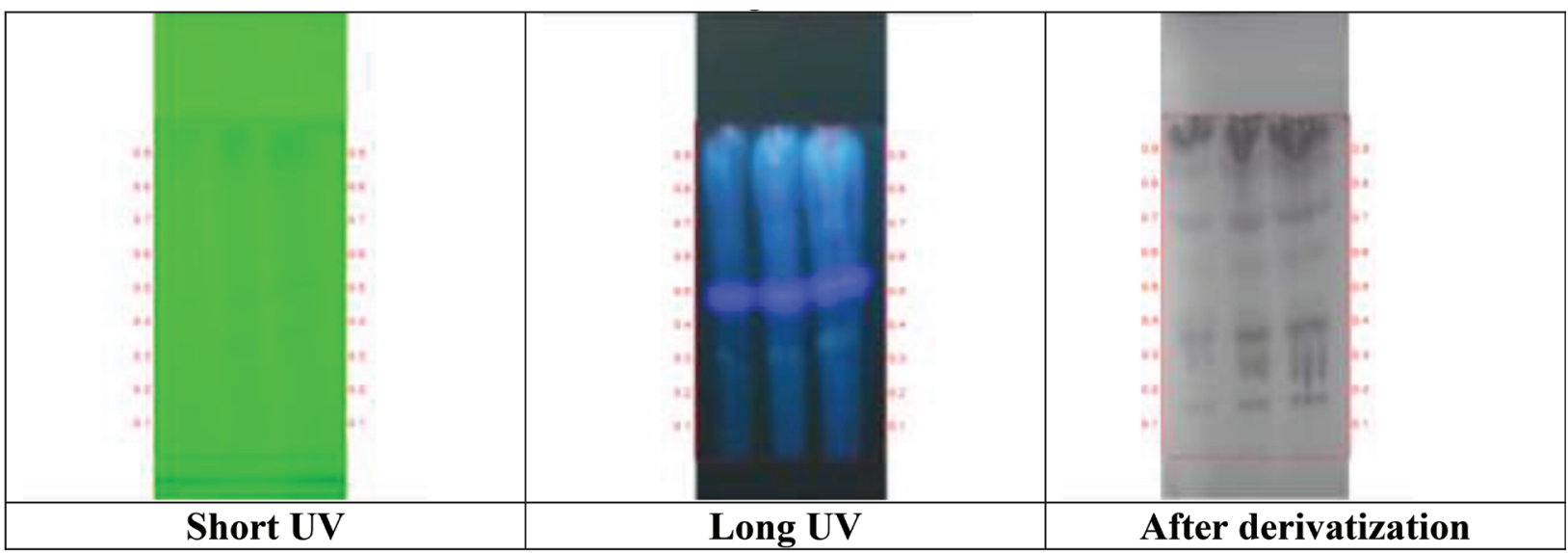

Track 1: HAMP $-4 \mu \mathrm{L}$

Track 2: HAMP $-8 \mu \mathrm{L}$

Track 3: HAMP $-12 \mu \mathrm{L}$

Solvent system: n-Butanol:acetic acid:water (4:1:1)

Fig. 1 High-profile thin layer chromatography (HPTLC) photo documentation of ethanolic extract of hydroalcoholic extract of Mucuna pruriens seeds (HAMP).

Table $3 R_{f}$ values of samples

\begin{tabular}{|l|l|l|}
\hline Short UV & Long UV & $\begin{array}{l}\text { After } \\
\text { derivatization }\end{array}$ \\
\hline- & - & 0.17 (D purple) \\
\hline 0.36 (D green) & 0.36 (F Aq. blue) & - \\
\hline- & - & 0.39 (D purple) \\
\hline- & - & 0.47 (L purple) \\
\hline 0.52 (D green) & 0.52 (FD blue) & - \\
\hline- & - & 0.59 (D purple) \\
\hline 0.61 (D green) & - & - \\
\hline- & - & 0.72 (D purple) \\
\hline- & - & 0.84 (D purple) \\
\hline
\end{tabular}

Abbreviations: D, dark; F, fluorescent; L, light; UV, ultraviolet.

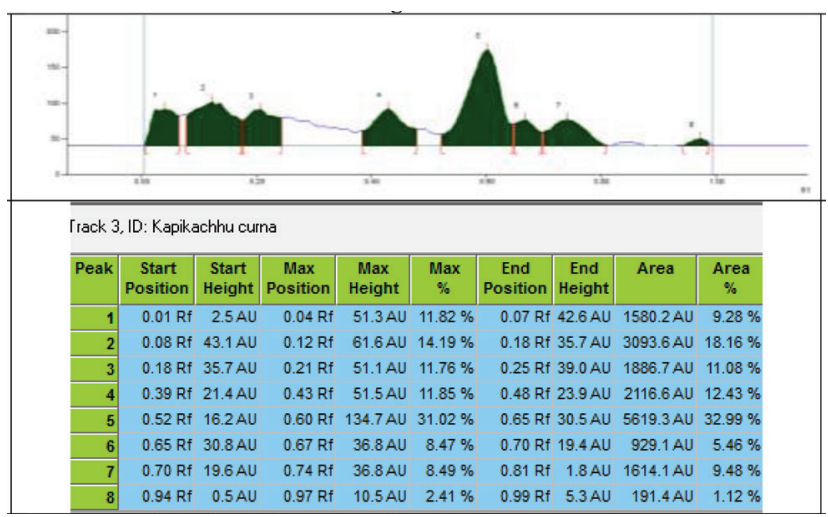

Fig. 2 Densitometric scan at $254 \mathrm{~nm}$.

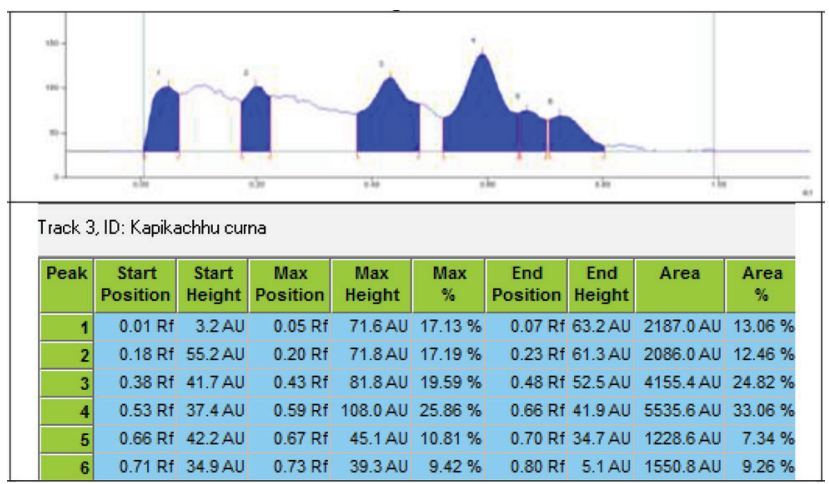

Fig. 3 Densitometric scan at $366 \mathrm{~nm}$.

documentation, the unique $\mathrm{R}_{\mathrm{f}}$ values, densitometric scan, and densitogram obtained at different wavelengths from HPTLC can be used as a fingerprint to identify HAMP powder. Similar findings about the presence of the compounds in the MP has been reported by several authors. ${ }^{39,40}$ Several reports on MP about anti-venoum, ${ }^{41}$ hypoglycemic, ${ }^{42}$ anti-Parkinson's, ${ }^{11}$ antimicrobial, ${ }^{43}$ antioxidant, ${ }^{44}$ and aphrodisiac activity ${ }^{45}$ has been documented. Our present phytochemical analysis of HAMP also confirms similar types of compounds found in other studies. Thus, it can be used for further various clinical trials.

\section{Conclusion}

By preserving the fundamental aspect of the Ayurvedic drug, standardization requires a rational approach. The main 


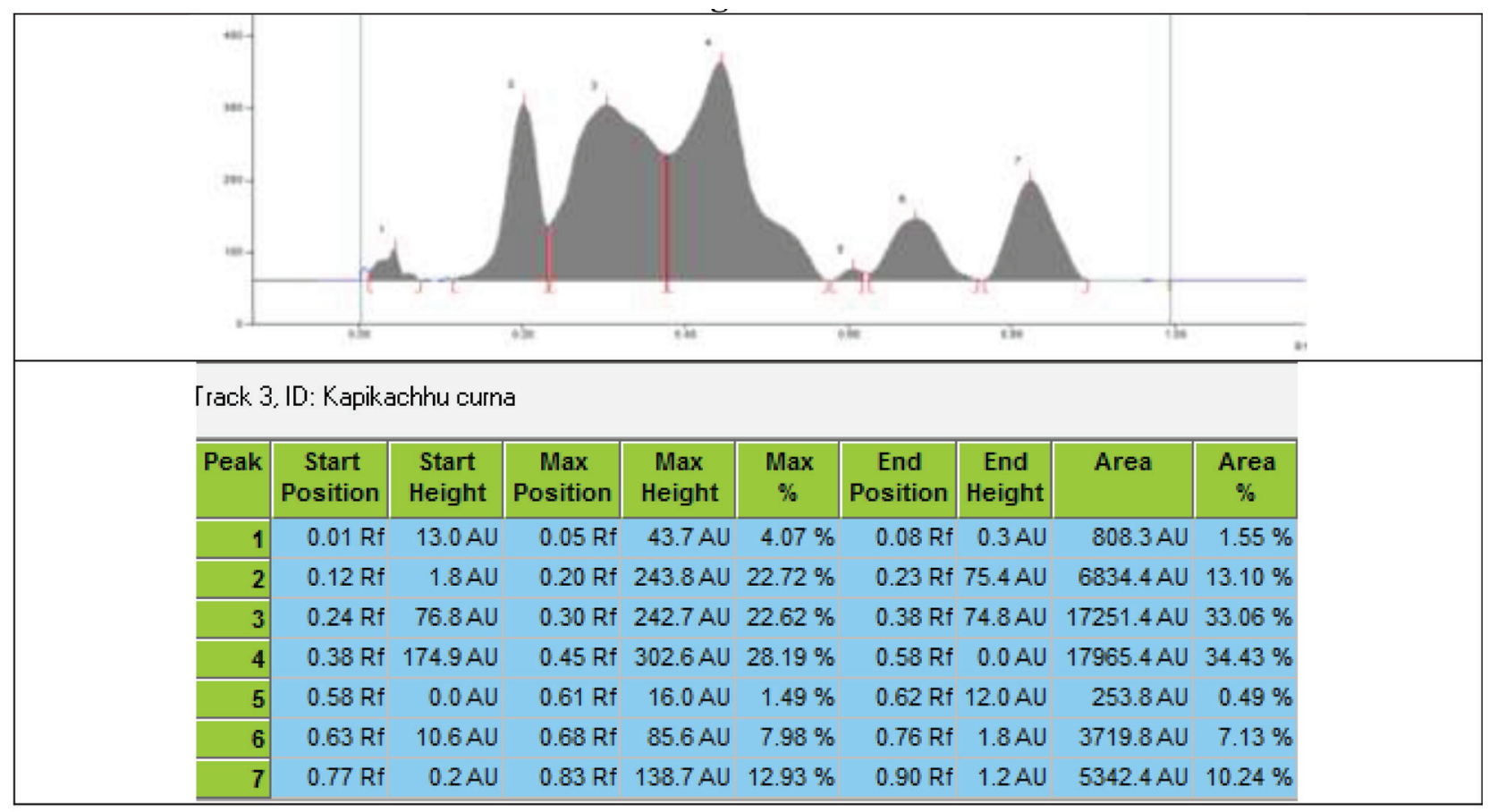

Fig. 4 Densitometric scan after derivatization at $620 \mathrm{~nm}$.

obstacle in the standardization of the Ayurvedic drug is the identification of its biological source. Drugs from different geographical source may vary with its active constituent and it may not be feasible to standardize drug chemically. The parameters used in this work ensure the quality control of HAMP. The results found through this study were rapid, reproducible, and could be used for routine monitoring of HAMP. HAMP is endowed with various biological properties and hence efforts have been made here to provide scientific data on the same.

\section{Conflict of Interest}

None declared.

\section{Acknowledgments}

The authors sincerely would like to thank Sri Dharmastala Ayurveda Medical College and Research Center, Udupi, Karnataka, India, for providing plant material for this study; the Management of Subbaiah Institute of Medical Sciences and Research Center, Shivamogga; and the Management of K. S. Hegde Medical Academy, Deralakatte, Mangalore.

\section{References}

1 Arun Raj GR, Shailaja U, Prasanna N. Rao AS, Thomas NP. Review on the contribution of Ura-Marunnu, a traditional baby care practice in southern India. Pharma Innovation 2014;2(11):42-70

2 Kimmatkar N, Thawani V, Hingorani L, Khiyani R. Efficacy and tolerability of Boswellia serrata extract in treatment of osteoarthritis of knee-a randomized double blind placebo controlled trial. Phytomedicine 2003;10(1):3-7
3 Arun Raj GR, Shailaja U, Rao PN, Sharanesh T, Gokul J. Review on the contribution of Dashapushpa, a traditional medicine in the management of cancer. Glob J Res Med Plants Indig Med 2013;2(9):656-663

4 Chaudhary RR, Herbal Medicine for Human Health. World Health Organization, Geneva. New Delhi: CBS Publishers and Distributors LTD; 1999:5

5 Somanathan AR, Sadanandan K, Damodaran NP. Standardisation of ayurvedic medicines-dasamulam kasayam. Anc Sci Life 1989;9(2):54-60

6 Dart RC, Caravati EM, McGuigan MA, et al. Medical Toxicology. 3rd ed. Philadelphia: Lippincott Williams \& Wilkins; 2004

7 Bressani R. Factors influencing nutritive value in food legumes, Mucuna compared to other grain legumes. Food and feed mucuna: current use and the way forward. Proceedings of an international work shop on food and feed from mucuna: current uses and the way forward. Tegucigalpa, Honduras, April 26-29, 2002:164-188

8 Sharma ML, Chandokhe N, Ghatak BJ, et al. Pharmacological screening of Indian medicinal plants. Indian J Exp Biol 1978;16(2):228-240

9 Rajeshwar Y, Gupta M, Mazumder UK. Antitumor activity and in vivo antioxidant status of Mucuna pruriens (Fabaceae) seeds against Ehrlich ascites carcinoma in Swiss albino mice. Iran J Pharm Ther 2005;4(1):46-50

10 Reddy VB, Iuga AO, Shimada SG, LaMotte RH, Lerner EA. Cowhage-evoked itch is mediated by a novel cysteine protease: a ligand of protease-activated receptors. J Neurosci 2008;28(17):4331-4335

11 Katzenschlager R, Evans A, Manson A, et al. Mucuna pruriens in Parkinson's disease: a double blind clinical and pharmacological study. J Neurol Neurosurg Psychiatry 2004;75(12):1672-1677

12 Lieu CA, Kunselman AR, Manyam BV, Venkiteswaran K, Subramanian T. A water extract of Mucuna pruriens provides long-term amelioration of parkinsonism with reduced risk for dyskinesias. Parkinsonism Relat Disord 2010;16(7):458-465 
13 Vamsi S, Raviteja M, Kumar GS. In-vitro antiurolithiatic potential of various extracts of. Mucuna pruriens. Int J Pharm Sci Res 2014;5(9):3897

14 Akhtar MS, Qureshi AQ Iqbal J. Antidiabetic evaluation of Mucuna pruriens, Linn seeds. J Pak Med Assoc 1990;40(7):147-150

15 Sathiyanarayanan L, Arulmozhi S. Mucuna pruriens Linn. A comprehensive review. Pharm Rev 2007;1(1):157

16 Sruthi T, Satyavati D, Upendar K, Kumar CP. Antidiabetic activity and anti-oxidant activity of niddwin, a polyherbal formulation in alloxan induced diabetic rats. Int J Pharm Sci 2014;6(2):273-277

17 Kumar DS, Muthu AK, Smith AA, Manavalan R. In vitro antioxidant activity of various extracts of whole plant of Mucuna pruriens (Linn) Int J Pharm Tech Res 2010;2(3):2063-2070

18 Champatisingh D, Sahu PK, Pal A, Nanda GS. Anticataleptic and antiepileptic activity of ethanolic extract of leaves of Mucuna pruriens: a study on role of dopaminergic system in epilepsy in albino rats. Indian J Pharmacol 2011;43(2):197-199

19 WHO, Quality Control Methods for Medicinal Plant Materials. Geneva. Delhi: AITBS Publishers and Distributors; 2002:65-67

20 The Ayurvedic Pharmacopeia of India, Government of India, Ministry of Health and Family Welfare, Department of Ayurveda, Yoga and Homoeopathy (Ayush), New Delhi, Part-1; edition; 2001 1(5):1

21 Indian Pharmacopoeia, Ministry of Health and Family Welfare, Government of India, New Delhi; 2010 Vol I:10-146

22 Nayeem AA, Khatun A, Rahman MS, Rahman M. Evaluation of phytochemical and pharmacological properties of Mikania cordata (Asteraceae) leaves. J Pharmacognosy Phytotherapy 2011;3(8):118-123

23 Evans WC, Trease and Evans Pharmacognosy. Singapore: Hartcourt Brace and Company, Asia Pvt. Ltd; 1997 226-227

24 Wagner H, Pharmazeutische Biology. 5th ed. AUFI. 15 BN 3-437-20 498-X. Stuttgart, Germany: Gustav fisher Vwelag; 1993

25 Neelima N, Devidas NG, Sudhakar M, Javid KV. A Preliminary phytochemical investigation on the leaves of Solunum Xanthocarum. IJRAP 2011;2(3):845-850

26 Foulger $\mathrm{JH}$. The user of the Molisch ( $\alpha$-naphthol) reactions in the study of sugars in biological fluids. (PDF) J Biol Chem 1931;92:345-353

27 Filling H. Die quantitative Bestimmung von Zucker und Stärkmehl mittelst Kupfervitriol. The quantitative determination of sugar and starch by means of copper sulfate. Annalen der Chemie und Pharmacie 1849;72(1):106-113

28 Simoni RD, Hill RL, Vaughan M. Benedict's solution, a reagent for measuring reducing sugars: the clinical chemistry of Stanley R. Benedict. J Biol Chem 2002;277(16):10-11

29 Nath MC, Chakravorty MK, Chowdhury SR. Liebermann-Burchard reaction for steroids. Nature 1946;157(3978):103-104

30 Levine VE, Richman E. A test for cholesterol based upon the use of sulphuric acid containing selenious acid. Exp Biol Med 1930;27(8):832-833
31 Auwal MS, Saka S, Mairiga IA, Sanda KA, Shuaibu A, Ibrahim A. Preliminary phytochemical and elemental analysis of aqueous and fractionated pod extracts of Acacia nilotica (Thorn mimosa) Vet Res Forum 2014;5(2):95-100

32 Zohra SF, Meriem B, Samira S, Alsayadi MM. Phytochemical screening and identification of some compounds from Mallow. J Natl Prod Plant Resour 2012;2(4):512-516

33 Usman H, Abdulrahman F, Usman A. Qualitative phytochemical screening and in vitro antimicrobial effects of methanol stem bark extract of Ficus thonningii (Moraceae) Afr J Tradit Complement Altern Med 2009;6(3):289-295

34 Pasto DJ, Johnson CR, Miller M, Experiments and Techniques in Organic Chemistry. Englewood Cliffs, NJ: Prentice-Hall; 1992 (PJM)

35 Nidhin PS, Yaligar MG, Arun Raj GR, Koppala Narayana Sunil Kumar RM. Standardization of Harithaki (Terminalia chebula Retz.) and Trivrit (Operculina turpethum L.) churna: two important drugs used for purgation in Ayurveda. J Pharmacogn Phytochem 2015;4(1):203-209

36 Mosettig E. The synthesis of aldehydes from carboxylic acids. Org React 2004;8:218-257

37 Shabi Ruskin R, Vasantha Kumari B, Chitarasu T. Qualitative phytochemical and FTIR analysis of root extracts of Canthium Parviflorum Lam. JCHPS 2014;2:122-127

38 Geiss F. Fundamentals of Thin Layer Chromatography Planar Chromatography. Heidelberg: Hüthig; 1987. ISBN 3-7785-0854-7

39 Krishnaveni M, Hariharan D. Phytochemical analysis of Mucuna pruriens and Hyoscyamus Niger seeds. Int J Pharma Bio Sci 2017;7(2):6-13

40 Duke AT, Handbook of Medicinal Herbs. 3rd ed. London: CRS Press; 1995 p. 220

41 Fung SY, Tan NH, Sim SM, Marinello E, Guerranti R, Aguiyi JC. Mucuna pruriens Linn. seed extract pretreatment protects against cardiorespiratory and neuromuscular depressant effects of Naja sputatrix (Javan spitting cobra) venom in rats. Indian J Exp Biol 2011;49(4):254-259

42 Liu Y, Xu X, Bi D, et al. Influence of squalene feeding on plasma leptin, testosterone \& blood pressure in rats. Indian J Med Res 2009;129(2):150-153

43 Kumar A, Rajput G, Dhatwalia VK, Srivastav G. Phytocontent screening of Mucuna seeds and exploit in opposition to pathogenic microbes. J Biol Environ Sci 2009;3(9):71-76

44 Kumar DS, Muthu AK. Free radical scavenging activity of various extracts of whole plant of Mucuna pruriens (Linn): an in-vitro evaluation. J Pharm Res 2010;3(4):718-721

45 Shukla KK, Mahdi AA, Ahmad MK, Jaiswar SP, Shankwar SN, Tiwari SC. Mucuna pruriens reduces stress and improves the quality of semen in infertile men. Evid Based Complement Alternat Med 2010;7(1):137-144 